\title{
Progrès réalisés par les turbines hydrauliques au cours des dernières années
}

\author{
(suite et fin) (**)
}

\author{
Hydraulic turbine development \\ during the last few years ${ }^{(*)}$ \\ (continuation and end) (*;*)
}

PAR A. PUYO

DIRECTEUR DE LA DIVISION GROS MATERREL NEXRPIC

\begin{abstract}
La technique des turbines hydrauliques, bien que d'origine ancienne, vient d'accomplir des progrès encore étonnanls au cours de ces quinze dernières années.

Avec les progrès accomplis par les constructeurs électriciens et par les moyens de génie civil, il doit en résulter des perspectives prometteuses pour l'hydraulique, malgré la concurrence des autres sources d'énergie.

Ces progrès ont été dirigés principalement dans le sens de l'économie, dans le sens d'une plus grande facilité d'exploitation et dans le sens de la prolongation de la vie des machines. Ceci s'est traduit, d'une part, par des résultats spectaculaires tels que l'augmentation des puissances unitaires, l'augmentation des vitesses de rotation et la réduction des poids des machines, d'autre part par d'autres améliorations moins apparentes portant principalement sur la technologie mais dont l'incidence est également notable quant d̀ la qualité des services rendus par ces machines.

Enfin, nous avons assisté également à la création et au développement de nouveaux types de machines tels que les. Pelton verticales, les bulbes et les turbines-pompes. Ces rouvelles solutions, sans nul doute, contribueront a rendre plus compétitive l'énergie hydraulique au cours des prochaines années.
\end{abstract}

\begin{abstract}
The technique of hydraulic turbines originated many years ago, but it has nevertheless been possible to make amazing progress in the course of the last fifteen years.

In conjunction with the progress made by generator manufacture $\widehat{F} s$ as well as on the civil engineering side, the future prospects for hydraulic power are extremely promising despite the competition from other sources of energy. Progress has been made principally with regard to improved economy, greater case of operation and longer equipment life. This has led, on the one hand, to spectacular results such as increased unit outputs and rotational speeds and a reduction in the weight of the equipment; and, on the other hand, to less obvious improvements, mainly in the technological field, the incidence of which is none the less remarkable with regard to machine performances. Furthermore we have seen the creation and the development of new types of machines, such as vertical-shaft impulse turbines, bulb units and pump-turbines. These new solutions will without doubt contribute towards making hydraulic power more competitive in the course of the coming years.
\end{abstract}

\section{IV. - TURBINES BULBES \\ IV. - BULB TURBINES}

J'en viens maintenant au dernier-né de la famille des turbines hydrauliques, dont ces dernières années ont vu sinon la naissance mais le prodigieux développement. Je veux parler des groupes «bulbe ». Ce sont des « turbines-hélice

(*) Conférence prononcée à Mexico, lor's des Journées techniques de l'exposition française, le 23 octobre 1962.

$\left(^{\star *}\right)$ Voir no 1-1963, pp. 3 à 41 .
'Bulb' units, which are the latest addition to the turbine family, have undergone tremendous development during recent years. They are horizontal-shaft propeller turbines with fixed or adjustable guide vanes and runner blades.

(**) Paper read in Mexico, on occasion of the Technical Meetings at the French Exhibition (23rd Oct. 1962). $\left({ }^{\star \star \star *}\right)$ See No. 1, pp. 3 à 41 . 
d'axe horizontal », le distributeur et les pales pouvant être fixes ou mobiles. L'appellation qui convient le mieux est celle de «turbines axiales », puisque l'axe de la turbine coincide avec l'axe de l'écoulement (fig. 29).

II serait trop long d'en faire ici l'historique. Que ce soit en Amérique, en Europe, tout spécialement en Allemagne, et en France dans notre maison, l'idée en est assez ancienne. Je dois me limiter à l'ère des grandes réalisations véritablement industrielles, qui ne remontent pas au-delà des années récentes.

Les turbines hélice ou Kaplan classiques, avec bâche spirale et aspirateur coudé, conduisaient à des installations extrêmement onéreuses pour les très basses chutes.

Pour abaisser le seuil de rentabilité, il était
They are most appropriately considered as 'axial turbines' as their centre line coincides with that of the flow (Fig. 29).

A complete review of their origin and development would be outside the scope of this discussion, but it is worth noting that the idea is a fairly old one which has been the subject of considerable research both in the United States and in Europe, and especially by the French firm we represent. We shall therefore merely confine our discussion to the period during which major industrial projects have been undertaken, that is to say the last few years.

Conventional propeller or Kaplan turbines with spiral casings and draught elbows have been found to be a very costly form of equip-

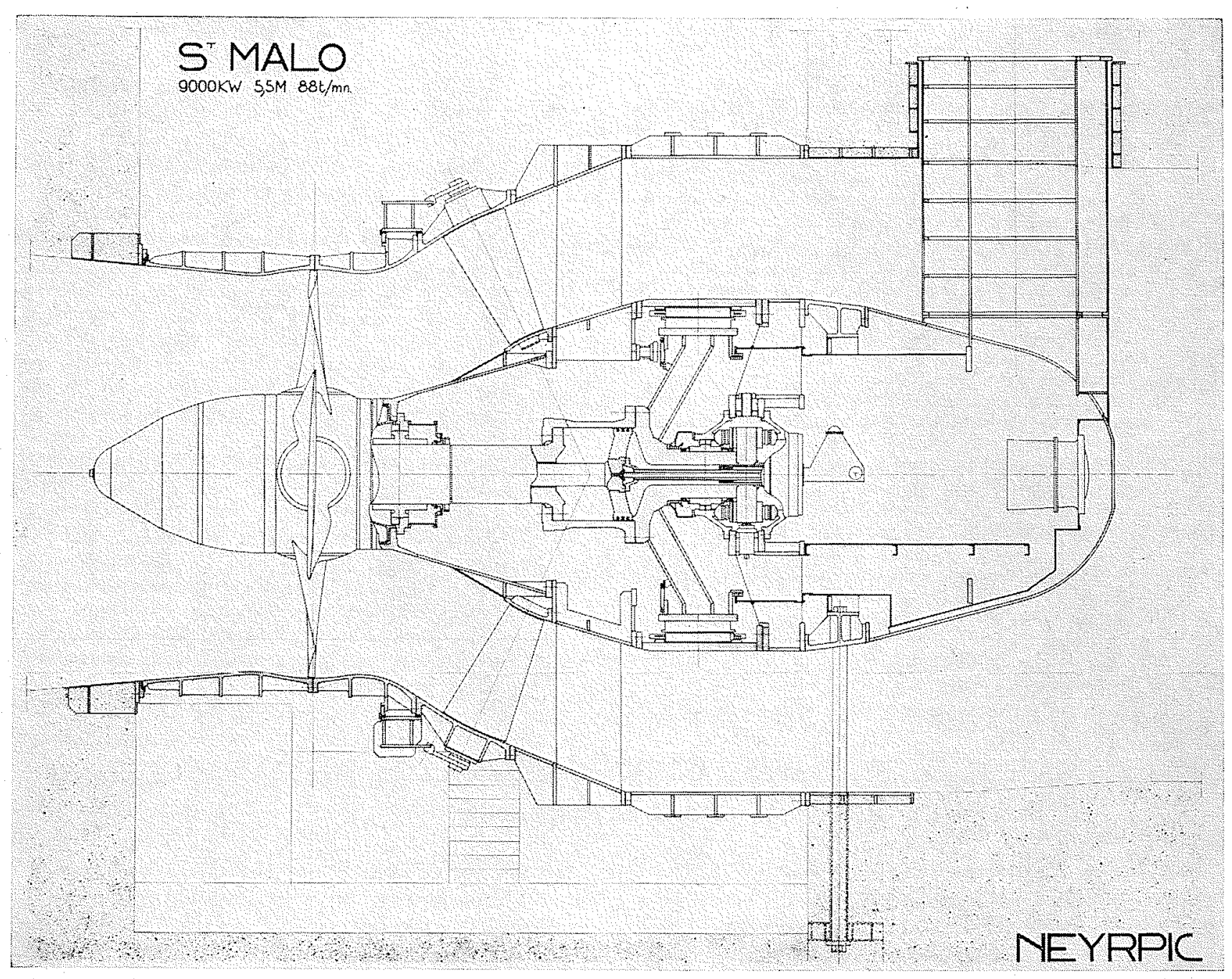

FIG. 29

Saint-Malo (caractéristiques : roir fig. 23). Coupe de la turbine.

Saint-Malo (characteristics: see Fig. 23). Longitudinal section through the unit. 
nécessaire de faire appel à des techniques nouvelles permettant de réaliser des économies massives sur le prix des ouvrages de génie civil et sur le matériel électro-mécanique. En diminuant notablement l'importance des changements de direction de l'écoulement dans la turbine, on peut, à la fois, augmenter la puissance spécifique, c'est-à-dire diminuer les dimensions des roues capables de développer une puissance donnée sous une chute donnée, diminuer le volume des terrassements et des maçonneries pour une même dimension de roue, simplifier les formes des pièces élémentaires de la turbine.

Cette tendance était déjà marquée dans les turbines Kaplan verticales munies d'un distributeur conique, telles que nous en avions installées dès 1935

C'est l'utilisation de l'énergie marémotrice, entreprise en France, qui a permis d'aboutir à des résultats vaiment remarquables.

Notre maison étudic le problème des usines marémotrices, et spécialement de la Rance, depuis 1942, et les groupes bulbes ont connu un développement spectaculaire sous l'impulsion donnée à ces études pour le projet de la Rance, aujourd'hui en cours de réalisation, avec vingtquatre groupes de $11000 \mathrm{~kW}$.

\section{Avantages des bulbes sur les Kaplan.}

Au point de vue matériel électromécanique, la disposition axiale de la turbine, avec alimentation conique, permet l'utilisation de forts débits spécifiques, compatibles avec l'obtention de bons rendements.

Le tracé des conduits d'amenée dans le distributeur des groupes axiaux permet d'obtenir une circulation plus faible à l'entrée de la roue, donc de bons rendements avec des puissances spécifiques élevées. En effet, les bons rendements nécessitent une faible rotation à l'amont immédiat de la roue. Une rotation excessive dans cette région est un des obstacles qui interdisent une vitesse spécifique très élevée dans les dispositions classiques comportant des bâches spirales.

Enfin le rendement d'un aspirateur rectiligne est bien meilleur que celui d'un aspirateur coudé.

Tous ces facteurs conduisent à des diamètres de roue de 7 à $8 \%$ inférieurs en bulbe, par rapport à la turbine Kaplan de même puissance sous la même chute, d'où une économie appréciable pour le matériel électromécanique (fig. 30).

Par ailleurs; la puissance spécifique est $20 \%$ supérieure pour un bulbe que pour une Kaplan de mêmes caractéristiques. Le rapport de la longueur du groupe au diametre de roue se réduit à 1,8 , contre 2,5 à 3 pour les Kaplan de basse chute. ment for very low head sites. New techniques have therefore had to be developed in order to reduce structural and electro-mechanical equipment costs and to arrive at a more profitable type of plant. Any substantial reduction in the directional changes of the flow through the turbine increases its specific output (i.e. a smaller runner produces the same output under a given head), reduces the excavation and concreting requirements for a given runner size, and simplifies the basic turbine components. This tendency was already most noticeable in the Kaplan turbines with conical guide vane assemblies we were supplying as far back as 1935.

The work done in France on the problem of harnessing tidal energy has produced some really remarkable results in this respect. Our company has been studying this problem since 1942, especially in connection with the Rance project, and considerable development progress has been achieved. The Rance tidal project is now actually under construction and is to feature 24 units producing $11,000 \mathrm{~kW}$ each.

\section{Advantages of bulb units over Kaplan turbines.}

The axial layout and converging inflow of the bulb turbine enable it to be run at high specific rates of flow, which are conducive to high efficiencies. The intake layout of an axial turbine reduces swirl at the runner entry and thus enables high efficiencies and specific outputs to be achieved. Low-swirl inflows to the runner are essential for high efficiencies, and excessive swirl at the runner intake is one of the factors which prevents any very high specific speeds from being achieved in conventional machines with spiral casings.

The straight draught tube of an axial unit is also much more efficient than the draught elbows of conventional turbines.

For these various reasons, bulb unit runner diameters are generally some $7 \%$ to $8 \%$ less than those of Kaplan turbines of the same output running under the same head, which results in an appreciable saving on electro-mechanical equipment costs (Fig. 30). Furthermore, specific outputs are $20 \%$ higher than with equivalent Kaplans, and the "power wnit length to runner diameter" ratio of a bulb unit is only 1.8 , against 2.5-3 for low-head Kaplan units.

As we have already seen, the characteristic specific power (i.e. the power produced by a $1 \mathrm{~m}$ diameter runner under a $1 \mathrm{~m}$ head) of a Kaplan unit is at most $27 \mathrm{HP}$, whereas figures of up to $36 \mathrm{HP}$ have been achieved with bulb units. At this condition, the kinetic energy below the runner is very nearly equal to the 


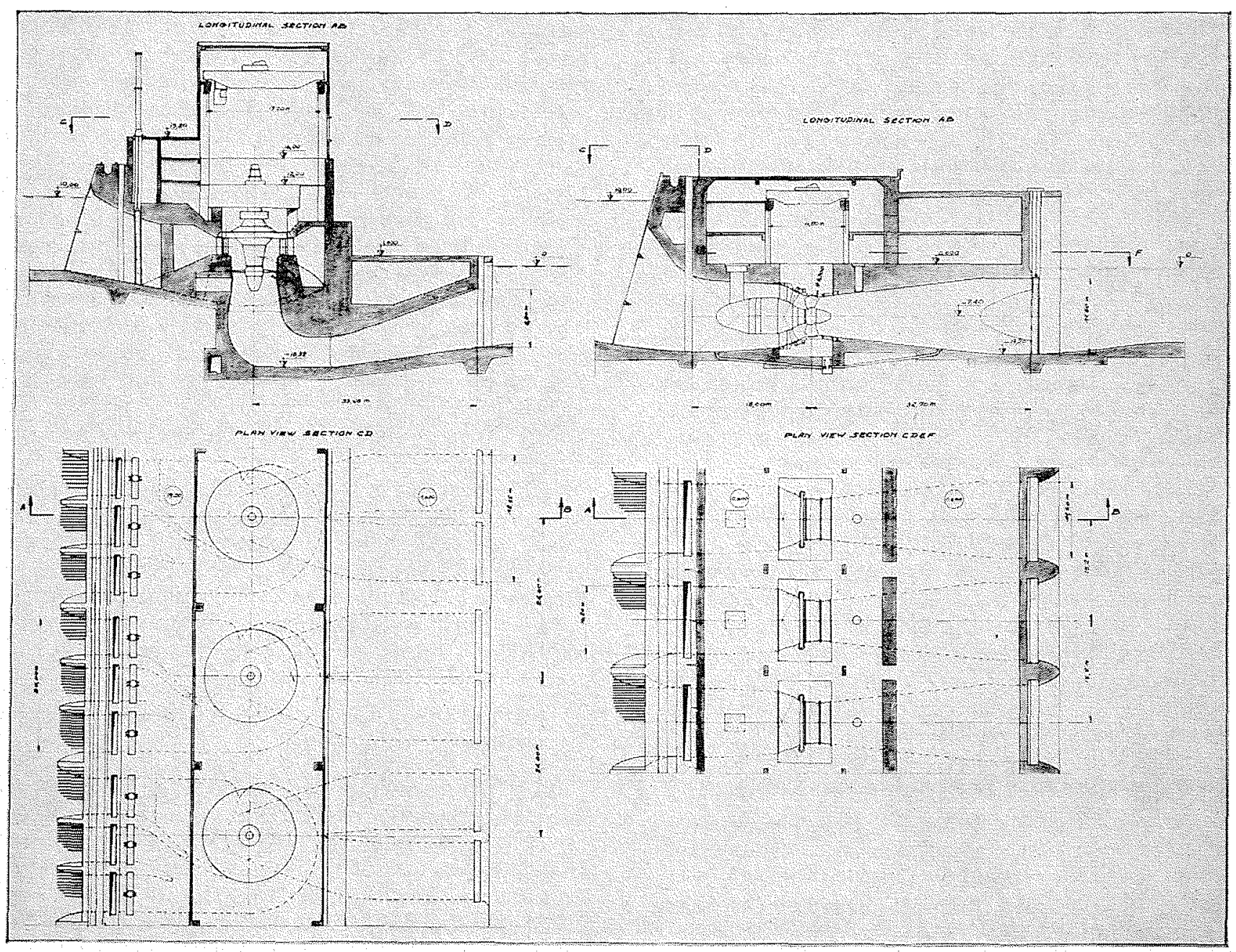

Frg. 30

\footnotetext{
Comparaison du génie civil pour une centrale de $75500 \mathrm{~kW}$ équipée de 3 turbines du type bulbe ou de 3 turbines Taplan. Coupes transversales et vues en plan.

Comparison between the structural requirements for a $75,500 \mathrm{~kW}$ plant with three bulb turbines and one with three Kaplan units. Plan and cross-sectional views.
}

Enfin la puissance spécifique caractéristique (puissance d'une roue de $1 \mathrm{~m}$ de diamètre sous $1 \mathrm{~m}$ de chute) atteignait, en Kaplan, au plus $27 \mathrm{ch}$ comme il a été dit. En bulbe, on arrive jusqu'à $36 \mathrm{ch}$. C'est-à-dire que l'énergie cinétique sous la roue est presque égale à la chute ou, si l'on préfère, l'aspirateur doit récupérer presque la totalité de l'énergie. Pour qu'il y parvienne, sa forme doit être très simple et son fonctionnement parfait.

Un autre avantage — et c'est même le principal au point de vue économique - des groupes bulbes sur les groupes Kaplan réside dans la réduction du génie civil. Le volume des fouilles d'abord, et du béton ensuite, est beaucoup plus faible par suite de l'absence d'une bâche spi- head; in other words, as the draught lube has to achieve practically $100 \%$ energy recovery, it must be very simple in shape and have a nearperfect worling efficiency.

A further attractive feature of bulb unitswhich is their main advantage from the economic point of view-is that they require much less structural work. Excavation and concreting requirements are much lower than for a Kaplan turbine mainly because of their straight draught tube and the absence of a spiral casing. The simpler structures they require also cost less to build, and the power units can be installed closer together than other turbines; for instance, twelve bulb units only take up the same amount of room as eight Kaplans of the same output. 
rale et d'un aspirateur coudé; les formes des ouvrages sont plus simples, plus économiques par conséquent; l'entre-axes des groupes est beaucoup plus réduit puisque on peut placer douze bulbes dans la longueur nécessitée par huit Kaplan de mème puissance. La superstructure de la centrale est très réduite, le corps de la centrale étant immergé. Des comparaisons très sérieuses ont été faites par les grandes sociétés, Electricité de France et Compagnie Nationale du Rhône, pour des chutes sur les grands fleuves, le Rhin et le Rhône, et conduisent à une économie de l'ordre de 30 à $35 \%$ par rapport à une centrale Kaplan verticale classique.

Si bien que le prix de revient du kilowatt installé est de $15 \%$ inférieur à celui de la mème centrale traitée selon le mode classique.

L'intérêt du bulbe par rapport à la Kaplan décroît quand la chute est plus importante. Actuellement son domaine d'application s'étend depuis les chutes très faibles (c'est le cas des turbines marémotrices à certains moments de la journée), jusqu'aux chutes de 15 à $16 \mathrm{~m}$ environ. L'accessibilité à l'intérieur du bulbe, en particulier pour parvenir au joint, qui est un des points délicats de la machine, est un des problèmes à résoudre.

Toute solution, si elle a des avantages, présente, bien entendu, quelque inconvénient : pour les bulbes, c'est leur inertie insuffisante. La réduction du diamètre de l'alternateur conduit en effet à une faible inertie et un temps de lancer global de 1,5 et $2 \mathrm{~s}$. Ces groupes ne doivent pas être installés sur des réseaux séparés présentant un faible coefficient d'autoréglage. Il faut les placer dans un réseau tel que d'autres centrales se chargent de régler les écarts de fréquence. Cependant, des études récentes et autorisées montreraient que cet inconvénient ne serait pas aussi grave qu'on le pensait jusqu'alors (4).

\section{Tendances actuelles pour les bulbes.}

Nous constatons déjà un accroissement de la puissance unitaire. Elle est limitée presque uniquement par les possibilités de refroidissement de l'alternateur, dont le diamètre est plus faible que celui de l'alternateur des solutions classiques.

Pour les turbines, la limite est donnée par le poids de la roue, située en porte-à-faux par rapport au palier aval du groupe. Par exemple, le palier de la turbine de Saint-Malo, prototype
Furthermore, as most of a bulb unit power house is under water, it only requires very little in the way of a superstructure. A number of important firms, as well as "Electricité de France" and "Compagnie Nationale du Rhône", have made some comprehensive comparisons for power sites on the Rhine and the Rhone, as a result of which it has been found that the saving achieved with bulb units works out at about $30 \%$ to $35 \%$ of the cost of a power plant equipped with conventional vertical-shaft Kaplan units. In terms of electricity output, this means a $15 \%$ lower cost 'per installed kilowatt' than with conventional power equipment.

The advantages of bulb units over Kaplans are less marked at high heads. Their present range of application extends from very low heads (i.e. as at certain times of the day at tidal power stations) up to about $15 \mathrm{~m}$ or $16 \mathrm{~m}$.

Accessibility to the inside of the bulb still remains a problem, however, especially as regards the seal, which is one of the most delicate parts of the machine.

Even the most successful designs are bound to have some disadvantages, however, and bulb turbines are no exception. With their small runner and alternator diameters, they suffer from low inertia, with the result that they have a regulation constant of between 1.5 and 2 seconds. This makes them unsuitable for use in isolated networks having a low self-regulation coefficient; they should, therefore, rather be installed in a system in which other power stations can deal with frequency variations. Recent research on this subject has shown, however, that this disadvantage may not be as serious, as it was first thought (4).

\section{Present bulb unit development trends.}

The present trend towards higher individual machine outputs is limited almost solely by the possibilities of cooling the alternator, which is smaller in diameter than that of a conventional power unit.

As far as the lurbines are concerned, this limit depends on the weight of the runner overhanging the downstream bearing in the unit. To give an example, the bearing in the Saint Malo turbine (a prototype we built for the Rance project) worked under a load of 110 tons, for a 6 metre runner diameter. As things are at the moment, the upper limit occurs for a runner diameter of about $7 \mathrm{~m}$.

The problem of cooling the alternator has been investigated extensively by electrical engineers, and especially by those of the Alsthom

(4) L'emploi des groupes bulbes pour l'équipement des grandes centrales hydroélectriques de basse chute (The use of bulb units for low-head hydro-electric power stations), par M. Farar. B. Favez et G. Ruelde. Conférence internationale des grands réseaux électriques à haute tension, 16-28 mai 1962. 
que nous avons réalisé pour la Rance, supportait un effort de $110 \mathrm{t}$ pour un diamètre de roue de $6 \mathrm{~m}$. Pour le moment la limite se situe autour d'un diametre de roue de $7 \mathrm{~m}$.

Le refroidissement de l'alternateur a fait l'objet de nombreuses recherches de nos collègues électriciens, et tout spécialement de l'Alsthom, qui a mis au point les groupes bulbes avec nous. La réduction, nécessaire, du diamètre du rotor ne permet pas d'utiliser les modes de refroidissement classiques. Suivant la taille de la génératrice électrique, plusieurs procédés sont utilisés.

Dans les microcentrales la génératrice, de petit diamètre, $1 \mathrm{~m}$ à $1,50 \mathrm{~m}$, est immergée dans
Company who collaborated with us in developing the bulb unit design. None of the usual cooling methods is suitable for the smalldiameter alternator rotors fitted to these units, so that a number of new methods had to be devised for the various alternator sizes involved.

In the case of the $1 \mathrm{~m}$ to $1.5 \mathrm{~m}$ diameter alternators used in 'micro' power stations, the problem has been solved by running the alternators in oil, which very efficiently conducts the heat away to the submerged bulb casing.

For higher-powered units, the idea has been adopted of keeping the bulb casing filled with air under pressure, as the power required to keep the coolant circulating decreases with the square of the pressure. This use of compressed

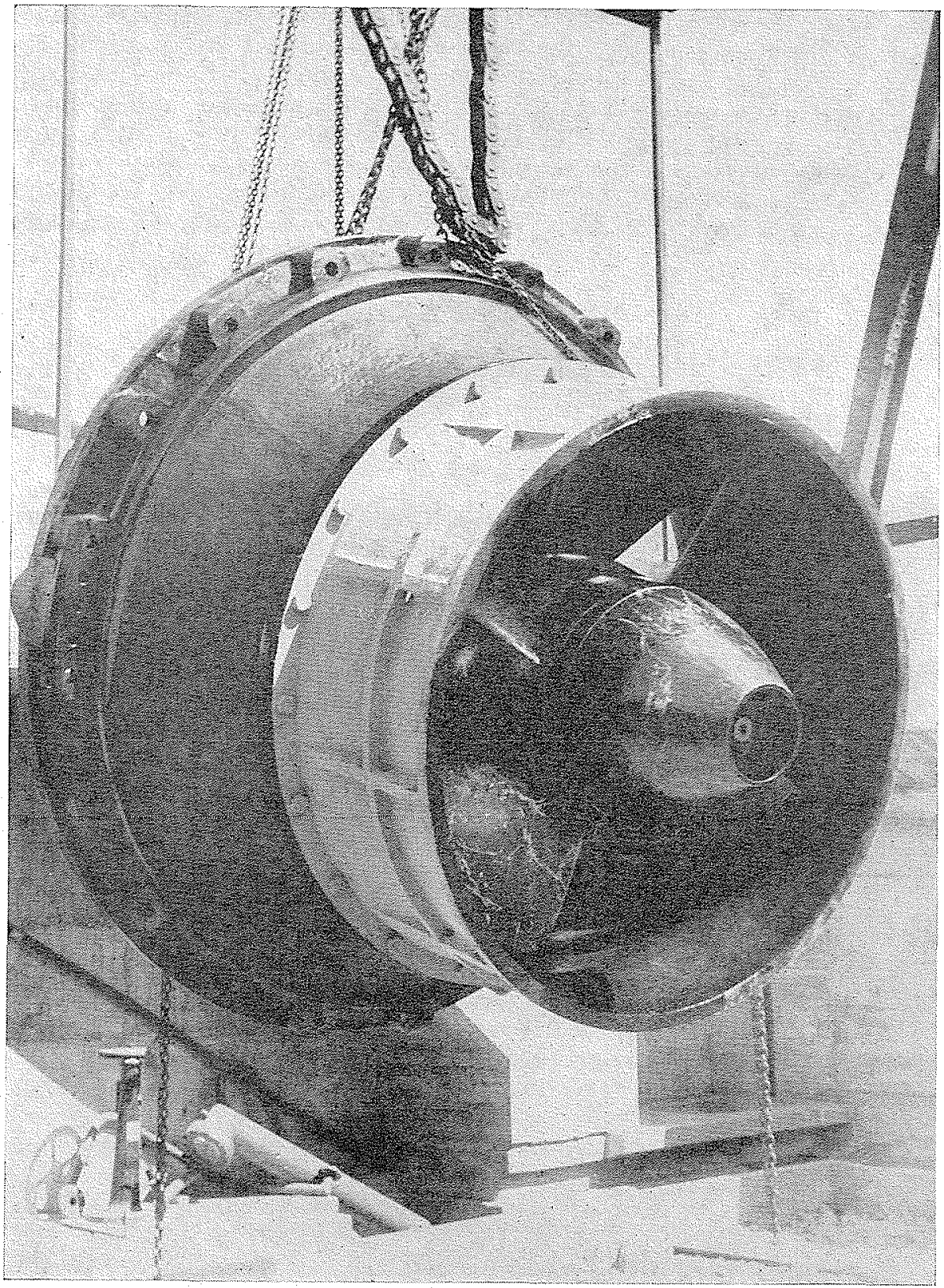

(Cliché Neyrpic.)
FiG. 31

Castet (S.N.C.F., France)

2 groupes bulbe amont. Puissance : $810 \mathrm{~kW}$.

Chute : $7 \mathrm{~m}$

Vitesse : $250 \mathrm{tr} / \mathrm{mm}$

Diamètre de roue : $1650 \mathrm{~mm}$ Ensemble d'un groupe monobloc en cours de manutention.

Castet, S.N.C.F., France. Two upstream,-bulb units. Output: $810 \mathrm{~kW}$. Head: $7 \mathrm{~m}$. Speed: 250 r.p.m.

Runner diameter: $1,650 \mathrm{~mm}$. Handling the turbine of a "monobloc" unit. 


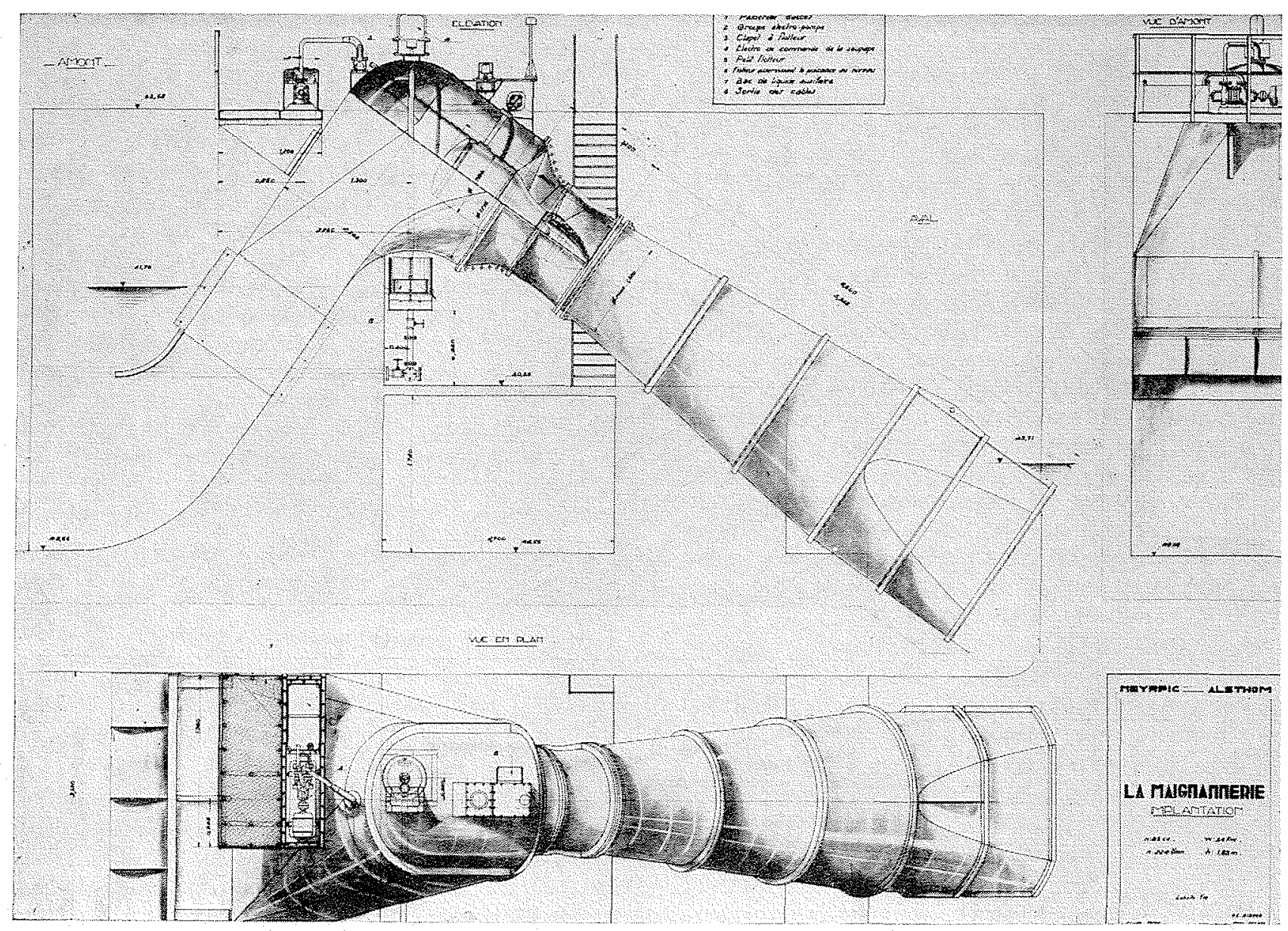

FIG. 32

La Maignannerie (France), 2 groupes bulbe amont en siphon.

Puissance : $65 \mathrm{~kW}$. Chute : $2,25 \mathrm{~m}$. Vitesse : $225 \mathrm{tr} / \mathrm{mn}$. Diamètue de roue : $1120 \mathrm{~mm}$. Ensemble d'un groupe monobloc immergé avec aspirateur tronconique droit et trompe d'entrée amont en siphon; pales fixes.

La Maignannerie, France. Two upstream-butb units, with siphon intakes. Output: $65 \mathrm{~kW}$. Head: $2.25 \mathrm{~m}$. Speed: $225 \mathrm{r} . \mathrm{p} . \mathrm{m}$. Runner diameter: $1.120 \mathrm{~mm}$. General view of a fixed-blade submerged "monobloe" unit with a straight diverging draught tube and a siphon intake.

de l'huile qui assure un échange thermique très efficace avec l'enveloppe du bulbe immergé.

Pour les groupes de grande puissance, l'intérieur du bulbe est rempli d'air comprimé. La puissance utilisée pour la circulation du fluide de refroidissement diminue en effet suivant le carré de la pression. Le refroidissement à l'air comprimé, expérimenté sur les groupes d'Argentat, est prévu pour les groupes de Pierre-Bénite, sur le Rhône, que nous exécutons avec l'Alsthom - $25000 \mathrm{ch}$ sous $12,50 \mathrm{~m}$ de chute - et pour les groupes de la Rance. Il entraîne par ailleurs un gain de rendement et permettra d'extrapoler les puissances réalisables en bulbes jusqu'à $40000 \mathrm{ch}$ environ. air as a cooling medium was first tried on the Argentat units, and has since also been adopted for those we are supplying with the Alsthom Company for Pierre-Benite on the Rhone, which will be producing $25,000 \mathrm{HP}$ under a head of $12.5 \mathrm{~m}$, and for the units in the Rance scheme. As this type of cooling also slightly increases the efficiency of the unit, it will be possible to extrapolate the outputs obtainable from bulb units to a figure of about $40,000 \mathrm{HP}$.

\section{Bulb unit categories.}

Bulb units fall within three distinct categories, each of which will now be described in turn. They are: 


\section{Les catégories de bulbes.}

$1^{\circ}$ La première famille comporte les bulbes de microcentrales; ils sont réservés aux faibles puissances (en dessous de $1500 \mathrm{ch}$ ) et aux faibles chutes (en dessous de $10 \mathrm{~m}$ ); le diamètre de roue atteint au maximum $2 \mathrm{~m}$ à $2,50 \mathrm{~m}$ (fig. 31).

Ces bulbes constituent un ensemble monobloc comprenant une turbine hélice entrainant directement une génératrice enfermée dans un carter étanche, profilé. Le distributeur de la turbine est fixe ou mobile, souvent fixe, l'alternateur est du type asynchrone à cage, sans bagues. L'huile qui remplit l'intérieur sert à la fois au refroidissement, au graissage des paliers, à l'isolement du stator et à l'étanchéité de l'ensemble, du fait d'une légère surpression par rapport à l'eau. Nous avons réalisé, dès 1953, avec l'Alsthom, le bulbe de Castet, qui donne toute satisfaction. Il a été suivi depuis par toute une série de machines analogues.

Des bulbes de microcentrales ont été équipés avec des alternateurs placés dans l'air à la pression atmosphérique, ce qui permet l'utilisation de machines électriques synchrones.

Le problème délicat des petits bulbes, problème aujourd'hui résolu, est celui du joint de l'arbre qui isole l'huile de l'eau qui cherche à s'infiltrer à l'intérieur.

Une disposition intéressante consiste à placer ces bulbes dans un siphon, pour les très basses chutes (fig. 32). Elle est extrêmement économique par la suppression de toutes vannes de garde, la coupure étant provoquée par le désamorçage rapide du siphon à l'aide d'une soupape d'entrée d'air.

$2^{\circ}$ Une seconde famille comporte ce que nous appelons les bulbes de rivière. Ce sont des turbines d'assez grandes dimensions, avec des roues de $3 \mathrm{~m}$ à $4,50 \mathrm{~m}$, dérivées de prototypes mis en route vers 1957-1958. L'un d'eux, installé près de Grenoble (fig. 33), comporte une roue de $3,800 \mathrm{~m}$ de diamètre, pour une puissance de $12400 \mathrm{ch}$ sous $12,50 \mathrm{~m}$ de chute. Ce groupe est à attaque directe, comme les gros groupes marémoteurs dont nous parlerons par la suite.

Mais on peut également construire des groupes avec multiplicateur de vitesse incorporé (fig. 34). Le multiplicateur, attaqué par la turbine, entraîne un alternateur du type classique, qui tourne à grande vitesse, et par conséquent d'un diamètre réduit. Si l'alternateur est économique, il faut ajouter le prix du multiplicateur qui reste un organe assez délicat. Le multiplicateur peut comporter des engrenages planétaires ou bien des engrenages cylindriques à un ou deux étages.

Des groupes analogues ont été installés, tout
1. "Micro" power station bulb units which are confined to low outputs and heads (i.e. up to $1,500 \mathrm{HP}$ and $10 \mathrm{~m}$ respectively). Their runner diameters do not exceed $2-2.5 \mathrm{~m}$ (Fig. 31).

These units are a single assembly consisting of a propeller turbine with a directly driven generator in a streamlined watertight casing. The guide vanes are either fixed or adjustable, frequently the former. The alternator is of the caged asynchronous type without slip rings. Oil in the casing simultaneously cools the machine, lubricates the bearings, insulates the stator assembly and, as it is at a slightly higher pressure than the water outside, seals the unit. The bulb unit of this type we built with the Alsthom Company for Castet in 1953 is still giving entirely satisfactory service, and several more similar machines have been built since.

Some 'micro' power station bulb units have also been provided with alternators running in air at atmospheric pressure, so as to enable synchronous generators to be used.

The delicate problem with small bulb units -which has now been solved-was to design a shaft seal that could be relied upon to prevent water from seeping into the oil in the casing.

An interesting arrangement is one used for very low head applications, in which the bulb units are installed in a siphon. (Fig. 32). This is a very economical layout, as the unit is shut down by making the siphon break by letting air into it via a vent valve, which does away with any need for the usual turbine shut-off valves.

2. River bulb units. These are fairly big turbines with runner diameters varying between 3 and $4.5 \mathrm{~m}$. They were developed from prototypes which were first put into service in about 1957 and 1958. One of them, near Grenoble (Fig. 33), has a $3.8 \mathrm{~m}$ diameter runner and is designed to produce $12,400 \mathrm{HP}$ under a $12.5 \mathrm{~m}$ head. As in most of the big tidal units we shall discuss later on, the alternator is driven directly by the turbine.

Units incorporating step-up gearing (Fig. 34) can also be built, with the turbine driving a conventional-type alternator which, as it is running at high speed, has a smaller diameter than usual. It should be noted, however, that though the alternator is less expensive in this case, the cost of the step-up gearing also has to be taken into account, which is a fairly delicate assembly either requiring a planetary gear system or, alternatively, single or two-stage spur gearing.

Units of this type have already been installed at certain power sites, especially in Germany. The limit of their output is determined by the 
FIG. 33

Beaumont-Monteux (France). Un groupe bulbe amont.

Puissance : $8800 \mathrm{~kW}$.

Chute : $12,48 \mathrm{~m}$.

Vitesse : $150 \mathrm{tr} / \mathrm{mn}$.

Diamètre de roue : $3800 \mathrm{~mm}$. Vue du groupe

en cours de montage,

depuis la conduite amont.

Beaumont-Monteux, France.

One upstream-bulb unit.

Output: $8,800 \mathrm{~kW}$.

Head: $12.48 \mathrm{~m}$.

Speed: 150 r.p.m.

Runner diameter: $3,800 \mathrm{~mm}$.

Cpstream view

of the power unit

during assembly.

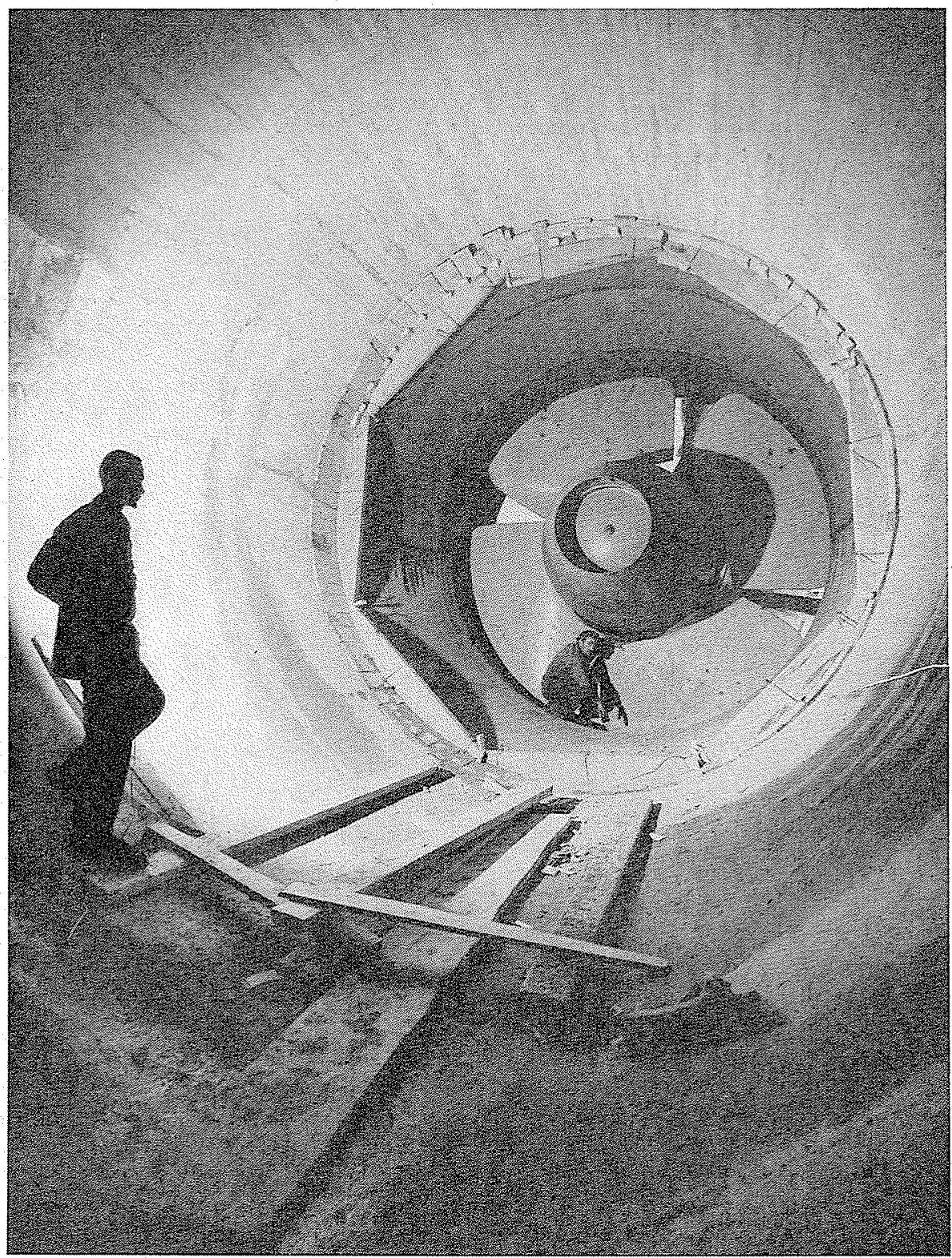

U.R.S.S. 1 groupe bulbe marémoteur expérimental.

Puissance : $415 \mathrm{~kW}$.

Chute : $1,28 \mathrm{~m}$.

Vitesses : $72 / 600 \mathrm{tr} / \mathrm{mm}$.

Coupe horizontale du groupe.

U.R.S.S. One tidal

experimental bulb unit. Oufput: $415 \mathrm{~kW}$. Head: $1.28 \mathrm{~m}$.

Speeds: 72/600 r.p.m.

(Cliché Neyrpic.)

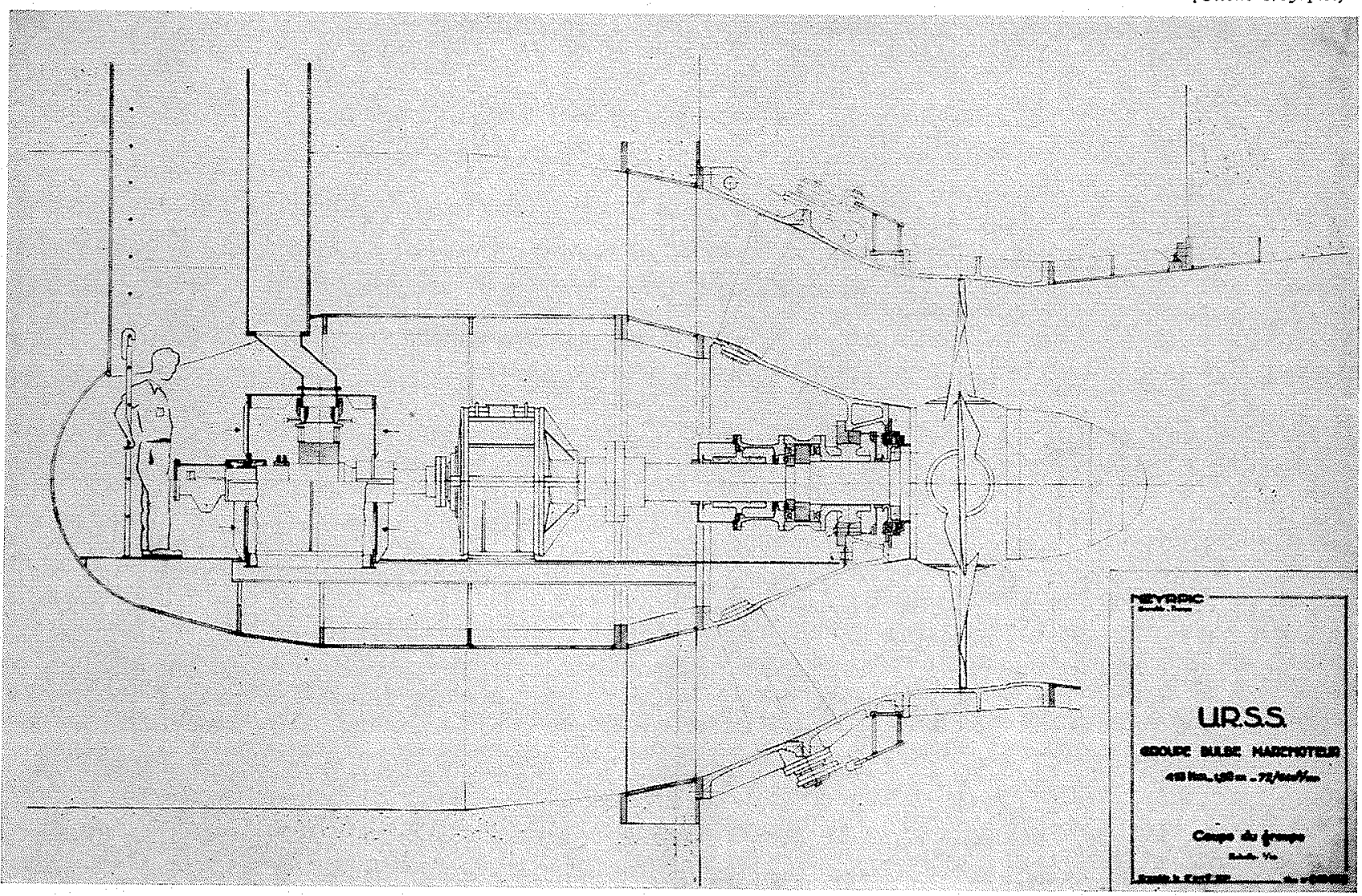




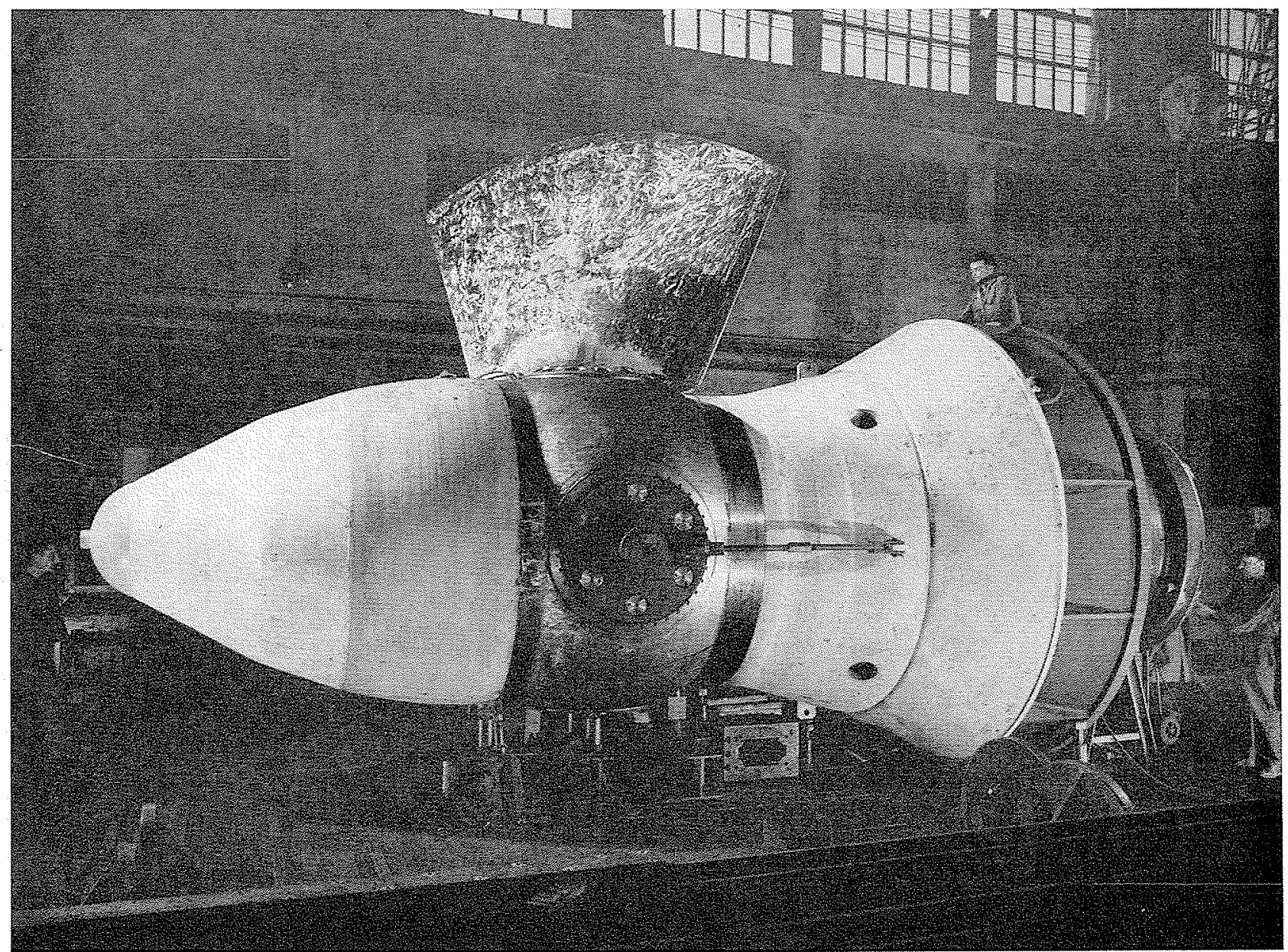

(Cliché Neyrpic.)

Fig. 35

Saint-Malo (caractéristiques : voir fig. 23).

Rotor. Ensemble avec ogive. Montage du groupe en atelier.

Saint-Malo (characteristics: see Fig. 23).

The rotor and spinner during assembly at the worlss.

spécialement en Allemagne. Leur limite est imposée par le multiplicateur qui ne dépasse pas une puissance de 7 à $8000 \mathrm{ch}$. Sans doute existe-t-il des multiplicateurs de $30000 \mathrm{ch}$, dans les centrales thermiques en particulier. Mais ils fonctionnent comme réducteurs de vitesse et les couples transmis sont assez faibles, les dentures des engrenages peu chargées. Il n'en est pas de même dans les groupes hydrauliques.

$3^{\circ}$ Enfin la troisième catégorie comporte les bulbes à entrainement direct pour les grands fleuves ou les centrales marémotrices. Ce sont ceux qui paraissent promis au plus grand avenir (fig. 35). La ventilation de l'alternateur s'effectue soit à la pression atmosphérique, soit à l'air comprimé à une pression de $2 \dot{a} 3 \mathrm{~kg} / \mathrm{cm}^{2}$. maximum power the gearing can take, which is no more than 7,000-8,000 HP. Though it is quite true that gear trains transmitting $30,000 \mathrm{HP}$ are in service-especially in thermal power stations-these are reduction gear systems which are transmitting comparatively low torque values and, therefore, only involve light gear tooth loadings. They work under very different conditions from those associated with hydraulic turbine step-up gearing.

3. Direct-drive bulb units for big rivers or tidal power stations. These seem to be the bulb units with the most promising future before them (Fig. 35). Their alternators are cooled with air at atmospheric pressure or at 2$3 \mathrm{~kg} / \mathrm{sq} . \mathrm{cm}$. 
Parmi les marémoteurs, nous avons en construction, avec Alsthom et d'autres constructeurs français, les vingt-quatre groupes de la Rance (fig. 36), et un groupe expérimental pour l'U.R.S.S. (avec multiplicateur, fig. 34). Parmi les groupes de fleuve, les quatres groupes de Pierre-Bénite, sur le Rhône.

Les groupes bulbes présentent l'avantage de pouvoir être utilisés en pompes. Ce sont des machines réversibles qui permettent - ce qui est le cas dans l'usine marémotrice de la Rance - de fonctionner dans les deux sens, soit en turbine, soit en pompe, suivant le niveau de la mer par rapport au niveau des bassins qui varie plusieurs fois par jour, et ceci sans changer les pales de la roue. Ils peuvent également être utilisés très facilement en orifice, en déchargeurs en quelque sorte; ce fonctionnement se présente dans les usines marémotrices quand la chute devient presque nulle.
The tidal units we are now building in collaboration with the Alsthom Company and other French manufacturers include, among others, the 24 units for the Rance project (Fig. 36) and an experimental unit for Russia, which latter is to feature step-up gearing. River units under construction include the four units for Pierre-Bénite on the Rhone.

An advantage of bulb units is that they can also be run as pumps. They are reversible machines which, as in the Rance projects, can be run either as turbines or as pumps without changing the runner bladings, depending on the difference between the sea level and the water levels in the basins, which vary several times during the day. They can also quite easily be used for relief purposes, in which case the unit is shut down and merely acts as an orifice; this type of operation occurs at tidal power stations whenever the head is practically nil.

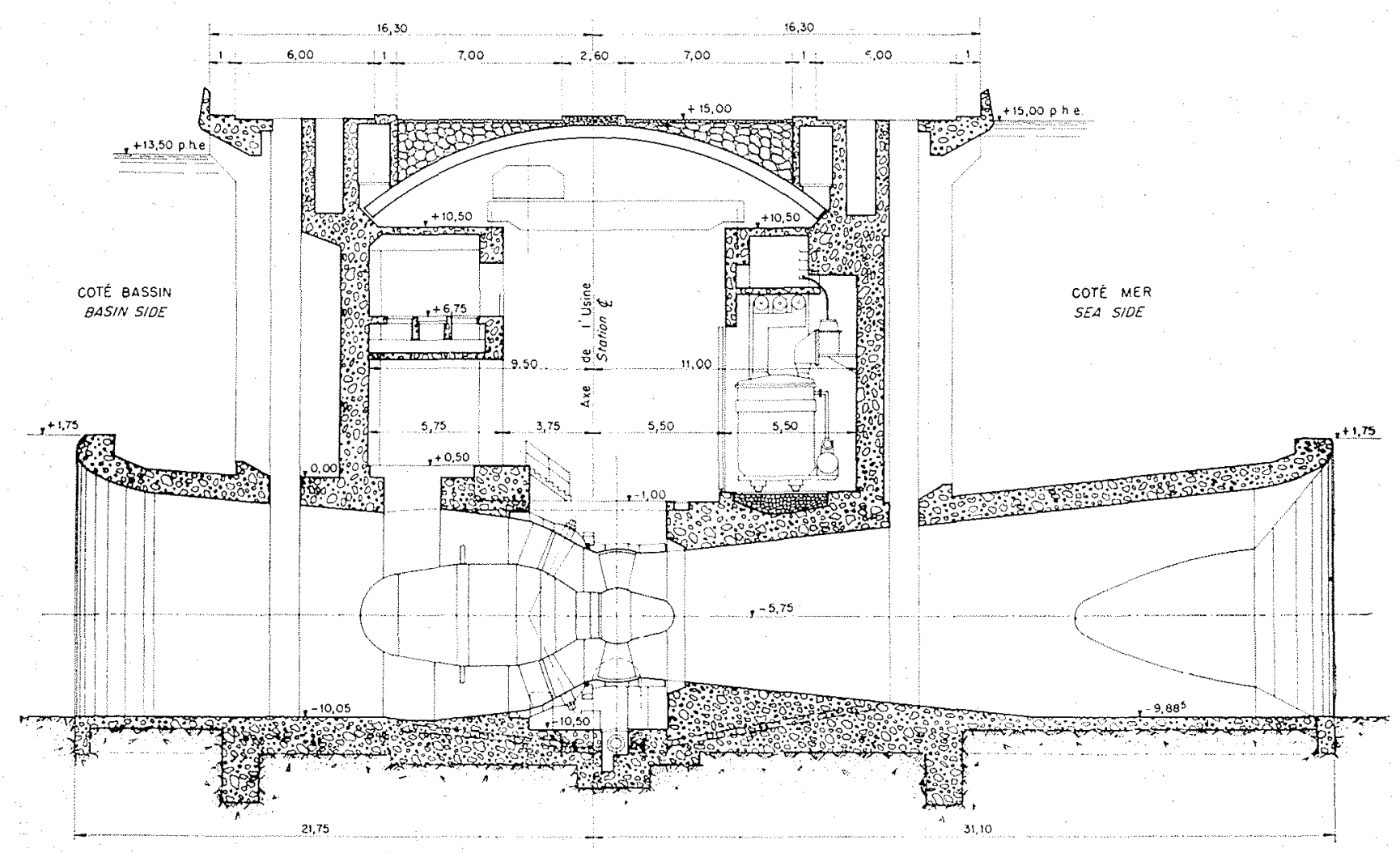

FIG. 36

Usine marémotrice de la Rance (France).

Puissance : $10000 \mathrm{~kW}$. Chute : $5,35 \mathrm{~m}$. Vitesse : $93,75 \mathrm{tr} / \mathrm{mn}$. Diamètre de roue $: 5350 \mathrm{~mm}$.

Plan d'implantation d'un groupe marémoteur; pales mobiles, distributeur mobile. Ces groupes doivent fonctionner, pour les deux sens d'écoulement, en turbine, en pompe et en orifice.

La Rance tidal power plant, France.

Output: $10,000 \mathrm{~kW}$. Head: $5.35 \mathrm{~m}$. Speed: $93.75 \mathrm{r} . \mathrm{p.m}$. Runner diameter: $5,350 \mathrm{~mm}$.

Layout of a power unit with adjustable runner blades and guide vanes.

These units are designed to run as turbines, pumps or straight-through orifices with the flow in either direction. 


\section{V. - TURBINES POMPES \\ V. - PUMP TURBINES}

Je terminerai avec un nouveau type de machine, les turbines-pompes.

Je ne parlerai bien entendu pas des pompes, ce n'est pas dans mon sujet. Cependant le problème du pompage prend chaque jour un intérêt plus grand. Malheureusement, l'eau est une matière première qui «se fera rare» dans le monde et il conviendra de l'utiliser avec beaucoup de précaution : usages agricoles, usages biologiques, usages industriels, avec la difficulté née de la pollution des eaux par l'industrie. Projets de dessalement de l'eau de mer
I shall complete this review with a few words about the pump turbine, which is quite a new type of machine. Though I shall not discuss pumps, as they are outside the scope of this subject, the fact that pumping problems are steadily gaining in importance should nevertheless be borne in mind. Water is a commodity which will unfortunately be becoming scarcer on a world-wide scale and great care will have to be exercised in its domestic, agricultural, industrial and other uses. The problem of water pollution by industrial sewage

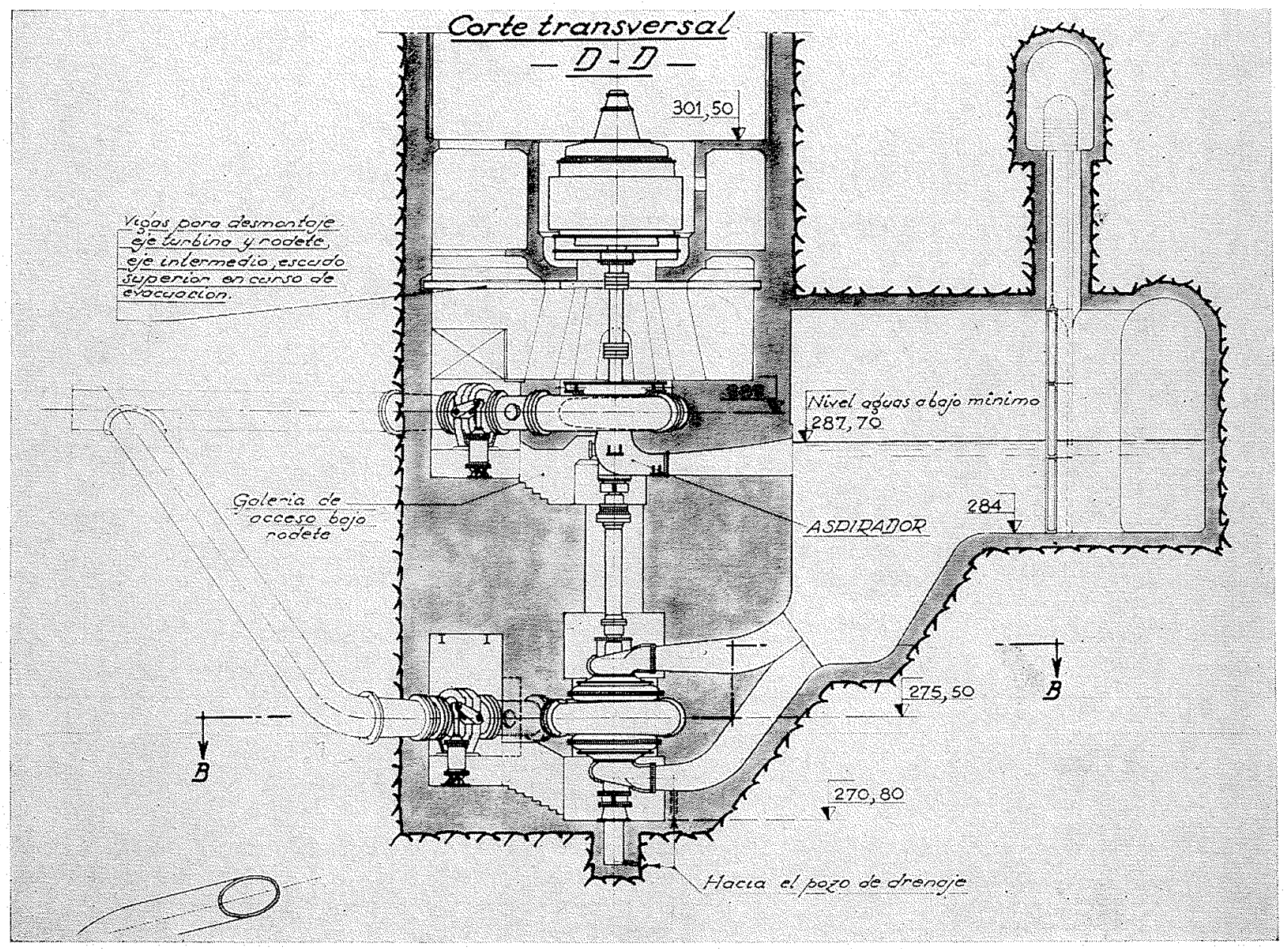

Fig. 37

Puente-Bibey (Espagne). 3 turbines Francis à axe vertical.

Puissance : $73500 \mathrm{~kW}$. Chute : $335,7 \mathrm{~m}$. Vitesse : $500 \mathrm{tr} / \mathrm{mn}$

Une $4^{\mathrm{e}}$ turbine, identique, est accouplée à une pompe de $16 \mathrm{~m}^{3} / \mathrm{s}$ sous $360 \mathrm{~m}$. Coupe transversale du groupe de pompage.

Puente-Bibey, Spain. Three vertical-shaft Francis turbines.

Output: $73,500 \mathrm{~kW}$. Head: $335.7 \mathrm{~m}$. Speed: 500 r.p.m.

A fourth identical turbine is coupled to a $16 \mathrm{~m}^{3} / \mathrm{s}$ pump discharging under $360 \mathrm{~m}$. Cross-sectional view of the furbine-pump unit. 
pour remettre les contrées stériles en cultures. Je ne m'étendrai pas sur ces sujets, hors du cadre de cet exposé, si ce n'est pour souligner l'importance, dans l'avenir, du problème du pompage pour l'industrie, et pour la vie de l'humanité dans son ensemble.

Si nous en restons aux problèmes d'énergie, les difficultés de réglage des réseaux, avec l'accroissement de puissance unitaire des groupes thermiques (250000 kW en Europe, $400000 \mathrm{~kW}$ en Amérique) et la présence de centrales nucléaires donnent un intérêt supplémentaire au pompage. Les grosses unités thermiques manquent de souplesse, le régime de marche des chaudières empêche des prises de charge rapides. Pour les centrales nucléaires, qui règlent très difficilement, la question est encore plus grave. Les centrales thermiques ou nucléaires et les centrales hydrauliques au fil de l'eau fournissant l'énergie de base, l'énergie de pointe sera donnée par des centrales hydrauliques alimentées par des retenues. L'intérêt de l'accumulation par pompage, absorbant l'énergie de déchet et restituant l'énergie de pointe, apparaît évident.

Ces installations ont comporté jusqu'à présent des groupes composés d'une turbine, d'une pompe et d'une machine électrique fonctionnant tantôt en alternateur, tantôt en moteur (fig. 37). Mais ces groupes sont très coûteux et leur installation assez compliquée. will have to be watched, and ways will have to be found of converting sea water into fresh water for the irrigation of barren land. All these subjects are well outside the scope of this discussion, however, and I have only mentioned them in order to stress the important bearing pumping problems will have on future domestic and industrial life in general.

As regards power production, the increasing difficulty of regulating distribution networks as greater individual thermal power station unit outputs are achieved $(250,000 \mathrm{~kW}$ in Europe, $400,000 \mathrm{~kW}$ in America) and the existence of atomic power stations both add to the importance of pumping. Big thermal power units lack operational flexibility because they depend on their boiler operating conditions which, as it happens, make it impossible for the units to take on loads very rapidly. The position is even worse in the case of atomic power plant, where major governing difficulties also arise. Thermal, atomic, and run-of-the-river power stations are the producers of basic electricity, whereas peak demand energy is supplied by hydraulic power stations receiving their supplies of water from reservoirs. The usefulness of pumped storage as a means of absorbing surplus energy and delivering it at peak demand periods is obvious.

Until now, pumped storage plants have
Fig. 38

Courbes de fonctionnement d'une machine réversible «turbine-pompe». Rendement maximal : en turbine, sous $88 \mathrm{~m}$; en pompe, sous $75 \mathrm{~m}$.

Operating : curves for a reversible pump-turbine. Maximum turbine efficiency occurs at $88 \mathrm{~m}$ head; maximum pump efficiency occurs at $75 \mathrm{~m}$ head.

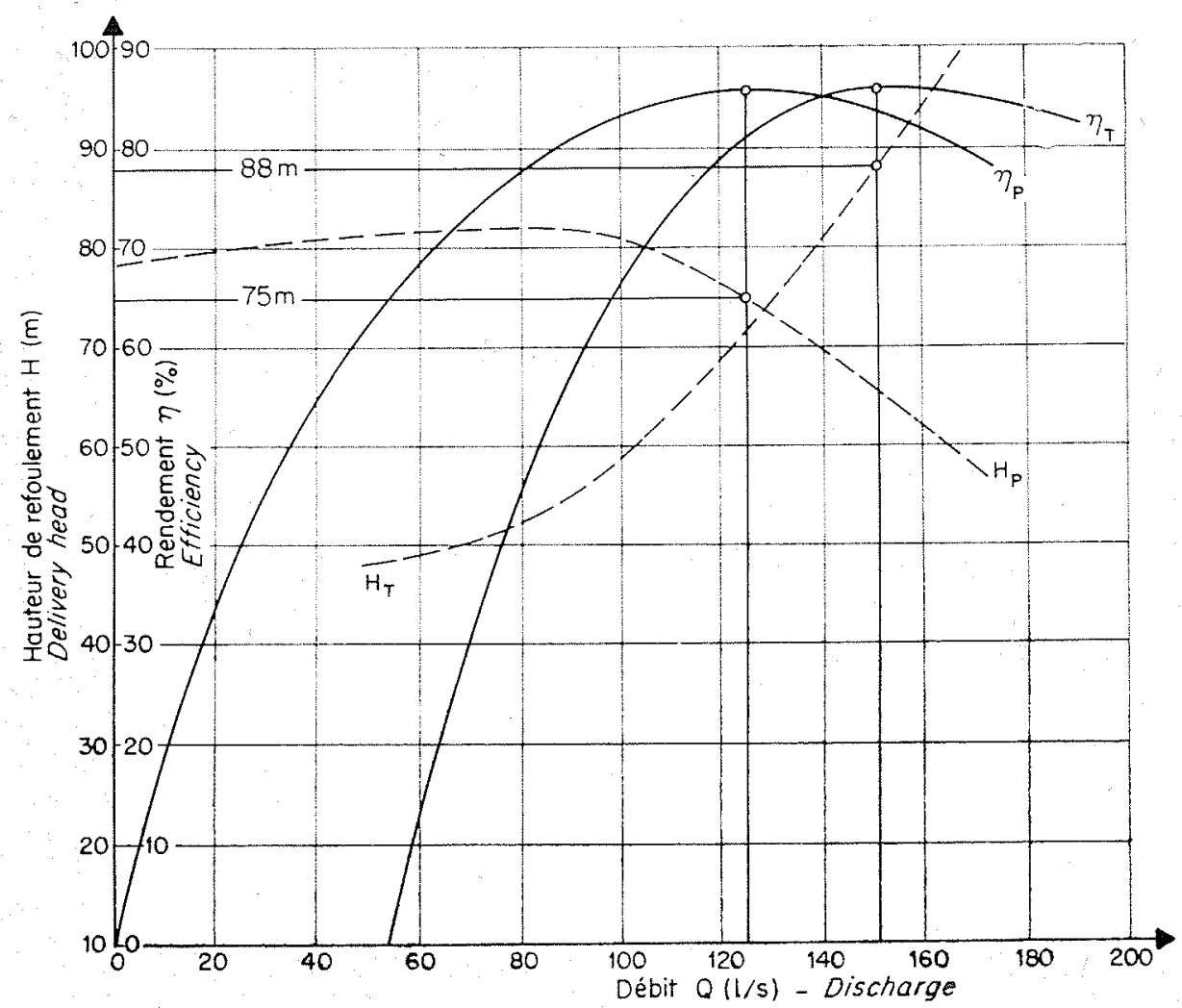




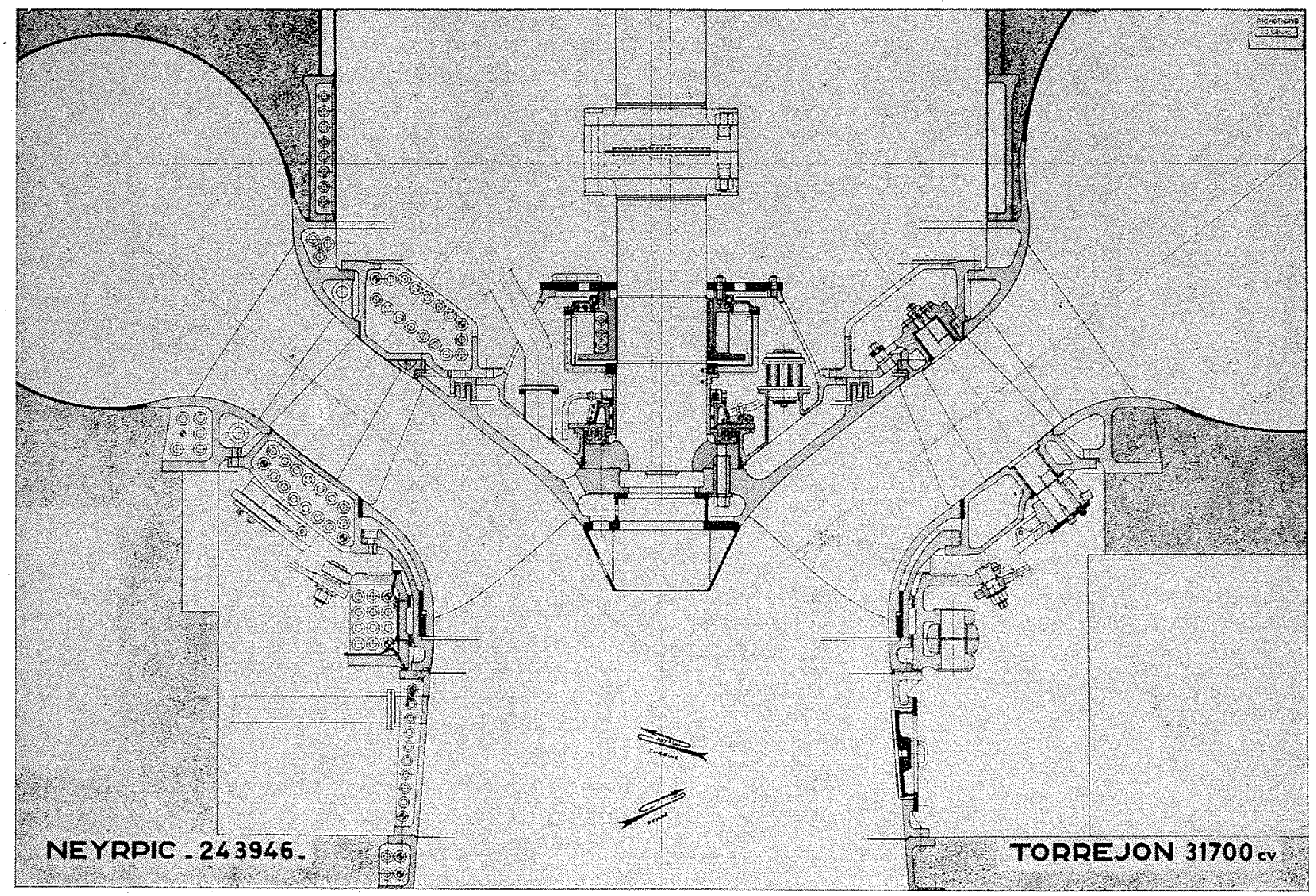

FIG. 39

Torrejon (Espagne). 4 turbines Francis à axe vertical.

Puissance en turbine : $33100 \mathrm{~kW}$. Chute : $47,70 \mathrm{~m}$. Vitesse : $107 \mathrm{tr} / \mathrm{mn}$.

Ces groupes fonctionnent également en pompe

avec un débit de refoulement de $63 \mathrm{~m}^{3} / \mathrm{s}$ à $24,50 \mathrm{~m}$.

Coupe verticale d'une turbine-pompe.

Torrejon, Spain. Four vertical-shaft Francis turbines.

Turbine output: $33,100 \mathrm{~kW}$. Head: $47.70 \mathrm{~m}$. Speed: 107 r.p.m.

These units can also run

as pumps discharging $63 \mathrm{cu} . \mathrm{m} / \mathrm{sec}$. for $a 24.5 \mathrm{~m}$ delivery head. Vertical pump-tarbine cross-section.

Une solution beaucoup plus astucieuse consiste à combiner en une seule machine la turbine et la pompe. Malgré son coût élevé, il est évidemment inférieur à ceux ajoutés d'une turbine et d'une pompe.

Au point de vue de la technique, une telle conception, à partir de ce que l'on sait des pompes centrifuges et des turbines Francis, n'a rien de révolutionnaire (fig. 38). Toutefois, il faut s'accommoder d'une certaine difficulté : Ies points de fonctionnement optimaux en turbine, d'une part, en pompe, d'autre part, dans un diagramme débit-pression, n'ont pas lieu pour la même pression; l'optimum en turbines se situe sous une pression plus grande que l'optimum en pompes. Si les données de l'installation sont réglées sur la turbine, la pompe est featured units comprising a turbine, a pump, and an electric machine running alternately as a generator and as a motor (Fig. 37). Such layouts are both very expensive and fairly complicated.

A much more functional solution is to combine the turbine and the pump as a single machine. Even though such a design is still quite expensive, it is obviously less. so than an installation with a separate pump and turbine.

A combined design based on present knowledge of centrifugal pumps and Francis turbines is by no means revolutionary from the technical point of view (Fig. 38). The only difficulty is that the respective pump and turbine operating points do not occur at the same pressure on the flow vs. pressure characteristic. The turbine 
désavantagée et réciproquement. De plus, comme la turbine fonctionne sous la hauteur statique diminuée des pertes de charge dans la conduite, et la pompe sous la hauteur statique augmentée des pertes de charge dans la même conduite, la hauteur de refoulement en pompe sera donc naturellement supérieure à la chute nette utilisée sur la turbine. C'est l'inverse de ce que l'on aurait désiré et il faut choisir un compromis.

Il y a plusieurs solutions pour concevoir une turbine-pompe.

Dans l'une, on part d'une turbine Francis, avec distributeur à aubes mobiles, mais les aubes de la roue sont également variables en position, de manière à réaliser un double réglage comme sur les turbines Kaplan. C'est une solution qui a donné lieu à des réalisations très intéressantes.

Une autre solution consiste à utiliser une turbine Francis proche des turbines classiques, mais dimensionnée différemment.

Dans une troisième disposition, que nous réalisons pour quatre turbines-pompes de $31700 \mathrm{ch}$ sous $32 \mathrm{~m}$ de chute, destinées à la centrale de Torrejon en Espagne (fig. 39), nous utilisons des roues dont le tracé est un compromis entre une roue de turbine et une roue de pompe, avec un distributeur conique.

Les turbines-pompes constituent probablement une solution promise à un grand avenir. requires a higher pressure, and if the design values for the installation depend on the turbine, the pump will be at a disadvantage, and vice-versa. In addition, since the turbine operates under the static head with the duct losses subtracted, and the pump runs under the static head plus the duct losses, the delivery head of the pump will obviously be greater than the net head driving the turbine. As this is the opposite of what is really required, a compromise has to be sought.

Several different pump turbine designs have been developed. One is based on a Francis turbine with adjustable guide vanes and, in addition, adjustable runner blades providing the same type of double control as on a Kaplan turbine. This layout has been used in a number of very interesting constructions.

An alternative is to use a Francis turbine similar to a conventional machine, but with different dimensions.

A third possibility is the layout we are using for four $31,700 \mathrm{HP}$ pump turbines designed for a $32 \mathrm{~m}$ head, which we are supplying for the Torrejon power plant in Spain (Fig. 39). The design of the runners in these machines is a compromise between a turbine runner and a pump impeller; the guide vane assembly is of the conical type.

There is little doubt that pump turbines have a brilliant future before them.

\section{CONCLUSION}

Cet exposé permet de juger l'importance et la diversité des progrès réalisés dans la construction des turbines hydrauliques.

Ces progrès se sont dirigés principalement dans trois directions :

Dans le sens de l'économie, par l'augmentation des puissances unitaires, l'augmentation des vitesses de rotation, le remaniement de l'architecture générale des groupes, tous éléments qui tendent à diminuer les dimensions et par conséquent les poids et les prix du matériel fourni; indirectement, à diminuer les dimensions de l'œuvre de génie civil dans lequel sont logées ces machines. Ceci s'est fail sans compromettre la sécurité, bien que la recherche de l'économie s'oppose quelquefois, dans une certaine mesure, à la recherche de la sécurité maximale.

Dans le sens d'une plus grande facilité d'exploitation, les efforts ont portés sur les modes de démontage, soit pour l'ensemble des groupes, soit pour les éléments, et aussi sur l'entretien, qu'on a voulu faciliter. Dans cette direction les
As we have seen in this brief review of recent hydraulic turbine design trends, some really remarkable results have been achieved. Progress has mainly been directed towards three distinct aims, which are the following:

(i) Improved economy, by increasing individual machine outputs and speeds, and a general redesigning of power unit structures; all these have combined in reducing the dimensions, and therefore also the weight and cost of the equipment supplied to power sites, as well as indirectly resulting in smaller civil engineering structures. None of all this has affected the reliability of the machines, despite the fact that the interests of economy and maximum reliability are sometimes in direct opposition:

(ii) Easier operation. Here, the accent has been on more convenient dismantling of whole power units or their components, and much attention has been given to more convenient 
perfectionnements se sont traduits assez souvent par une relative complication du matériel; ces complications sont venues réduire quelquefois les économies faites sur les dimensions des machines.

Dans le sens de la prolongation de la vie des turbines, ceci tout spécialement par la recherche de métaux mieux adaptés, bien que plus coûteux.

Enfin la création et le développement de nouveaux types de machines tels que les Pelton verticales, les Francis de hautes chutes, les bulbes et les turbines-pompes, ont rendu plus compétitive l'énergie hydraulique par rapport aux moyens de production concurrents.

Avons-nous atteint la limite? Très certainement non. Nous devons prévoir de nouveaux progrès dans la technique des machines hydrauliques qui leur permettront de garder une place de choix parmi les moyens d'utilisation, par l'homme, des forces mises à sa disposition par la nature. maintenance work. A point to note in this connection is, however, that these attempts have fairly often resulted in more complicated equipment, which has occasionally tended to offset the savings achieved by building smaller machines;

(iii) Longer turbine working life. Most of the efforts made in this connection have been aimed at finding more suitable metals, which are, however, also more expensive.

The development of such new machine types as the vertical-shaft Pelton turbine, the highhead Francis turbine, the bulb turbine and the turbine pump, has made hydraulic power more competitive with respect to other current forms of power production.

Has this development reached its limit? The answer is very certainly in the negative. Further progress in hydraulic machine design may still be expected to keep hydro-electric power in a leading position among the various means of harnessing the natural forces at Man's disposal.

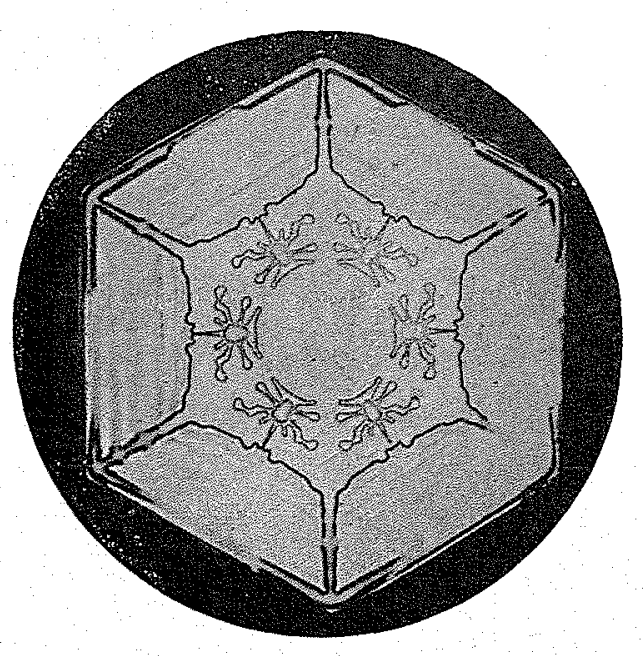

